\title{
Faktor Risiko Kejadian Distres Pernapasan pada Anak dengan Pneumonia
}

\author{
Karel Anggrek, Ari Lukas Runtunuwu, Audrey Wahani, Lusiana Margaretha \\ Bagian Ilmu Kesehatan Anak Fakultas Kedokteran Universitas Sam Ratulangi/RSU Prof. Dr. R. D. \\ Kandou Manado
}

Latar belakang. Distres pernapasan pada pneumonia merupakan kegawatan medis pada anak yang sering terjadi akibat berbagai faktor.

Tujuan. Mengetahui faktor-faktor risiko yang berhubungan dengan kejadian distres pernapasan pada anak dengan pneumonia.

Metode. Desain penelitian analitik observasional, cross sectional. Subjek penelitian adalah semua anak pneumonia berusia 2-24 bulan yang dirawat di Bagian Ilmu Kesehatan Anak RSU Prof. Dr. R.D.Kandou Manado Juni - Nopember 2005. Subjek dibagi menjadi kelompok pneumonia dengan dan tanpa distres pernapasan.

Hasil. Dari 68 kasus pneumonia, didapatkan 35 (51,5\%) disertai distres pernapasan dan 33 (48,5\%) tanpa distres pernapasan. Lama pendidikan ayah, lama pendidikan ibu, jumlah leukosit saat masuk rumah sakit, lama sakit di rumah, keluarga perokok dan hasil biakan darah mempengaruhi terjadinya distres pernapasan pada anak dengan pneumonia.

Kesimpulan. Lama pendidikan ayah, lama pendidikan ibu, jumlah leukosit, lama sakit di rumah dan keluarga perokok mempengaruhi terjadinya distres pernapasan pada anak dengan pneumonia. Secara bersama-sama faktor lama sakit di rumah, keluarga perokok dan hasil biakan mempunyai hubungan dengan kejadian distres pernapasan pada anak dengan pneumonia (Sari Pediatri 2008;9(6):391-7).

Kata kunci: pneumonia, distres pernapasan, faktor risiko

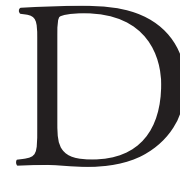

istres pernapasan merupakan kegawatan medis yang sering terjadi pada anak. Kemampuan penilaian klinis distres pernapasan serta perawatan yang baik

\footnotetext{
Alamat korespondensi

Dr. Ari Lukas Runtunuwu, Sp,A, Bagian Ilmu Kesehatan Anak FK UNSRAT/RSU Prof. Dr. R.D. Kandou Manado, Telp. (0431) 821652, Fax. (0431) 859091, Rumah: Jl. Santu Yoseph No. 19, Manado 95115 Telp. (0431) 827209; Hp: 085256215818
}

sangat penting, oleh karena dengan melakukan intervensi secara dini dapat menghindarkan pasien dari keadaan yang lebih parah atau bahkan kematian. ${ }^{1-5}$ Distres pernapasan merupakan diagnosis primer dari $50 \%$ anak yang dirawat di ruang perawatan intensif anak. Angka kematian bervariasi tergantung etiologinya, namun dilaporkan mencapai $40-75 \% .^{1,5}$

Penyebab distres pernapasan yang mengancam jiwa anak sangat banyak dan secara patofisiologis 
berbeda menurut penyakit dasarnya. Pada prinsipnya setiap keadaan yang menyebabkan obstruksi jalan napas atau yang mengganggu pertukaran gas dapat menyebabkan distres pernapasan. ${ }^{2,6}$ Pada anak, kerentanan terhadap infeksi saluran pernapasan merupakan predisposisi penting terjadinya distres pernapasan. $^{7}$

Infeksi saluran pernapasan akut (ISPA) merupakan penyebab utama kesakitan dan kematian pada bayi dan anak balita di negara berkembang. Sebagian besar hasil penelitian di negara berkembang menunjukkan bahwa 20\%-35\% kematian bayi dan anak balita disebabkan oleh ISPA, terutama pneumonia. Hampir semua kematian akibat ISPA pada anak adalah ISPA bawah dan hampir semuanya adalah pneumonia. ${ }^{8,9}$ Pneumonia adalah suatu penyakit infeksi parenkim paru dan termasuk dalam ISPA, khususnya infeksi saluran pernapasan bawah akut. Di negara berkembang penyebab utama pneumonia pada anak adalah bakteri (51\%) dan virus (25\%). Selain itu, juga dapat disebabkan oleh jamur, mycoplasma, dan lain-lain (24\%). Bakteri penyebab tersering adalah Streptococcus pneumoniae, Haemophylus influenzae, dan Staphylococcus aureus. ${ }^{10-13}$

Menurut analisis World Health Organization (WHO) dari 12,9 juta kematian anak tahun 1990, seperempat dari kematian anak usia di bawah lima tahun disebabkan oleh pneumonia, dan lebih dari $80 \%$ kematian anak oleh pneumonia terjadi di negara berkembang. Insiden pneumonia di negara berkembang 2-10 kali lebih banyak dibandingkan dengan di negara maju. Tiap tahun \pm 4 juta anak di negara berkembang meninggal karena pneumonia dan didominasi oleh kelompok usia di bawah 5 tahun. ${ }^{14}$ Di Indonesia, survei kesehatan rumah tangga tahun 1992 menunjukkan kematian yang disebabkan pneumonia sekitar 36,4\% dari seluruh kematian balita. Rata-rata angka kematian balita akibat pneumonia di beberapa propinsi Indonesia adalah 2,9 per 1000 balita. ${ }^{12,15}$ Di Sulawesi Utara, berdasarkan data Dinas Kesehatan Propinsi Sulawesi Utara, tahun 1997, terdapat 10.588 kasus pneumonia dengan jumlah terbanyak pada usia 1 bulan sampai 5 tahun, yaitu 9.217 kasus. ${ }^{16}$ Sementara data dari Bagian Ilmu Kesehatan Anak RSU Prof. Dr. R.D. Kandou Manado tahun 2002 menunjukkan bahwa dari 3.740 anak yang dirawat, 378 di antaranya $(10,1 \%)$ adalah pneumonia, 317 (83\%) dari kasus pneumonia tersebut berusia kurang dari 5 tahun, dan meninggal $10,5 \% \cdot{ }^{17}$
Berdasarkan hal-hal tersebut di atas, maka timbul permasalahan yang harus dijawab, yaitu bagaimana gambaran klinis, epidemiologi dan bakteriologi pneumonia pada anak di RSU Prof. Dr. R.D.Kandou Manado serta faktor-faktor risiko apa yang berhubungan dengan distres pernapasan anak pada anak dengan pneumonia.

Tujuan umum penelitian ini adalah memperoleh data dasar distres pernapasan akibat pneumonia pada anak. Tujuan khususnya adalah mendapatkan gambaran epidemiologi dan bakteriologi penyebab pneumonia pada anak di RSU Prof. Dr. R.D. Kandou Manado serta mengetahui faktor-faktor risiko yang berhubungan dengan kejadian distres pernapasan pada anak dengan pneumonia.

\section{Metode}

Penelitian bersifat analitik observasional dengan menggunakan rancangan penelitian cross sectional, dilakukan di Bagian Ilmu Kesehatan Anak Fakultas Kedokteran Universitas Sam Ratulangi/RSU Prof. Dr. R.D.Kandou, Manado. Waktu pengumpulan data dimulai Juni 2005 sampai Nopember 2005. Kriteria inklusi adalah anak berusia 2-24 bulan menderita pneumonia sesuai kriteria WHO, adanya ronki basah halus pada pemeriksaan auskultasi dan bercak-bercak infiltrat pada satu atau kedua lapangan paru pada foto toraks, dengan atau tanpa disertai adanya tanda-tanda distres pernapasan; serta mendapat persetujuan dari orang tua/wali untuk diikutsertakan dalam penelitian. Kriteria eksklusinya adalah disertai penyakit lainnya pada parenkim paru, saluran napas, pembuluh darah paru, pleura, dinding dada, sistem saraf dan otot pernapasan; penyakit kardiovaskular, penyakit susunan saraf pusat, atau infeksi berat seperti meningitis, sepsis yang disertai syok dan diare dengan dehidrasi; disertai tanda-tanda kegagalan pernapasan berupa penurunan kesadaran, napas lambat dan dangkal serta perfusi yang buruk. Besar sampel minimal adalah 68 anak. Gejala klinis pneumonia adalah apabila ditemukan demam, batuk, napas cepat/sesak napas, ditemukan ronki basah halus pada auskultasi paru dan gambaran infiltrat pada foto toraks. Distres pernapasan bila ditemukan tandatanda peningkatan kerja napas berupa pernapasan cuping hidung, retraksi dinding dada dan merintih (grunting). 


\section{Hasil}

\section{Karakteristik sampel}

Selama periode penelitian didapatkan 105 pasien pneumonia dari 1372 anak yang dirawat $(7,65 \%)$ terdiri dari $55(52,38 \%)$ laki-laki, $76(75,38 \%)$ berusia $\leq 24$ bulan, $51(48,57 \%)$ di antaranya berusia $\leq 12$ bulan. Kematian akibat pneumonia terjadi pada 5 $(4,76 \%)$ dari 105 kasus pneumonia yang dirawat atau $21,74 \%$ dari 23 kematian yang terjadi pada seluruh anak yang dirawat selama periode tersebut. Dari 76 pasien yang berusia $\leq 24$ bulan, 8 pasien tidak diikutsertakan karena 2 pasien berusia $<2$ bulan, 2 dengan penyakit jantung bawaan, 2 dengan meningitis dan 2 dengan diare dehidrasi. Enam puluh delapan persen pasien yang memenuhi kriteria inklusi, 35 $(51,5 \%)$ pasien disertai dengan distres pernapasan dan $33(48,5 \%)$ tanpa disertai distres pernapasan. Hasil biakan darah positif pada $33(48,53 \%)$ dari 68 sampel tersebut. Kuman yang ditemukan antara lain Staphylococcus pada 24 (72,73\%), Proteus pada 5 $(15,15 \%)$ dan Streptococcus, Klebsiela, Yersinia serta Micrococcus masing-masing 1 (13,03\%) pasien. Distribusi pasien pneumonia berdasarkan berbagai faktor dengan kejadian distres pernapasan tertera pada Tabel 1.

Hasil analisis statistik dengan uji regresi logistik menunjukkan terdapat hubungan bermakna antara lama pendidikan ayah $(\mathrm{p}=0,047)$, lama pendidikan ibu $(\mathrm{p}=0,038)$, jumlah leukosit $(\mathrm{p}=0,012)$, lama sakit di rumah $(p=0,007)$, dan adanya keluarga perokok di rumah $(\mathrm{p}=0,035)$ dengan kejadian distres pernapasan.

\section{Pembahasan}

Selama periode penelitian terdapat 7,65\% kasus pneumonia dari seluruh anak yang dirawat, lebih rendah dari yang dilaporkan oleh Sari $\mathrm{dkk}^{18}$ di RSU Praya Mataram tahun 1999 (17,21\%). Namun lebih tinggi dari yang dilaporkan oleh Lengkong $\mathrm{dkk}^{19} \mathrm{di}$ RSUP Manado tahun 1997-1998 (4,38\%). Pasien yang berusia $\leq 24$ bulan $75,38 \%$ hampir sama dengan yang didapatkan oleh Pattisahusiwa ${ }^{20}$ tahun 1999 (75,5\%) dan Lengkong ${ }^{19}$ tahun 1997-1998 (72,27\%). Wantania $^{22}$ mendapatkan rasio laki-laki : perempuan $=1,17: 1$, sementara menurut Sari $\mathrm{dkk}^{18} 1,4: 1$, peneliti mendapatkan rasio 1,59:1.
Kematian terjadi pada 4,76\% dari seluruh kasus pneumonia yang dirawat selama periode penelitian, lebih rendah dari yang dilaporkan oleh Lengkong $\mathrm{dkk}^{19}$ tahun 1997-1998 (9,24\%). Enam puluh delapan pasien yang dilakukan pemeriksaan biakan darah, ditemukan hasil positif sebanyak $48,53 \%$ dengan jenis kuman terbanyak adalah Staphylococcus (72,73\%). Beberapa kepustakaan mengatakan bahwa biakan darah menunjukkan hasil positif pada $1 / 4^{-1}{ }^{1} / 3$ kasus pneumonia. Spesies Staphylococcus saat ini merupakan salah satu kuman penyebab pneumonia di negaranegara berkembang dan terutama pada masa bayi, 70\% pneumonia Staphylococcus terjadi pada usia di bawah 1 tahun. $^{14,22}$

Angka kejadian distres pernapasan pada bayi dan anak jauh lebih tinggi dibandingkan orang dewasa, terutama disebabkan oleh maturitas struktur berbagai organ sistem ventilasi dan adanya kerentanan terhadap infeksi. Kira-kira 2/3 kasus distres pernapasan anak terjadi pada tahun pertama kehidupan. ${ }^{1,23}$ Sari $\mathrm{dkk}^{18}$ melaporkan kasus pneumonia berat terbanyak dijumpai pada anak usia $<1$ tahun, yaitu 53,85\% dari seluruh kasus pneumonia berat pada anak. Pada penelitian ini didapatkan distres pernapasan lebih banyak terjadi pada usia $2-12$ bulan $62,2 \%$ dari seluruh kasus.

Malnutrisi atau gangguan gizi pada anak selain merupakan faktor predisposisi terjadinya pneumonia, juga merupakan faktor risiko yang memperberat dan meningkatkan kematian pasien pneumonia. ${ }^{14,24}$ Sari $\mathrm{dkk}^{18}$ melaporkan bahwa mortalitas tertinggi akibat pneumonia terjadi pada pasien dengan status gizi buruk (46,67\%), gizi kurang $(11,43 \%)$ dan gizi baik $(4,76 \%)$. Didapatkan 2 pasien pneumonia dengan status gizi buruk, keduanya mengalami distres pernapasan.

Berat badan lahir rendah dan prematuritas merupakan faktor predisposisi baik terhadap kejadian pneumonia maupun terhadap kejadian distres pernapasan. ${ }^{1,23}$ Analisis meta menunjukkan bahwa bayi dengan berat badan lahir $<2,5 \mathrm{~kg}$ mempunyai risiko relatif kematian akibat infeksi, termasuk pneumonia 6,4 kali pada usia $<6$ bulan dan 2,9 kali pada usia 611 bulan. ${ }^{15}$ Tidak didapatkan hubungan antara berat badan lahir dan kejadian distres pernapasan.

Bayi yang mendapat ASI lebih jarang menderita penyakit karena adanya zat protektif dalam ASI seperti laktoferin, lisozim, komplemen $\mathrm{C}_{3}$ dan $\mathrm{C}_{4}, \mathrm{IgA}$ sekretori, IgE, IgM, IgG dan sel makrofag. Selain itu 
Tabel 1. Karakteristik pasien pneumonia dengan berbagai faktor risiko yang mempengaruhinya

\begin{tabular}{|c|c|c|c|c|}
\hline & \multicolumn{2}{|c|}{ Distres pernapasan } & \multirow{2}{*}{ Total (\%) } & \multirow{2}{*}{$\mathrm{p}$} \\
\hline & Positif (\%) & Negatif (\%) & & \\
\hline Umur (bulan) & & & & 0,058 \\
\hline - 2-12 & $23(62,2)$ & $14(37,8)$ & $37(100)$ & \\
\hline - 13-24 & $12(38,7)$ & $19(61,3)$ & $31(100)$ & \\
\hline Jenis kelamin & & & & 0,054 \\
\hline - Laki-laki & $21(63,6)$ & $12(36,4)$ & $33(100)$ & \\
\hline - Perempuan & $14(40,0)$ & $21(60,0)$ & $35(100)$ & \\
\hline Status gizi & & & & 0,402 \\
\hline - Baik & $11(47,8)$ & $12(52,2)$ & $23(100)$ & \\
\hline - Kurang & $22(51,2)$ & $21(48,8)$ & $43(100)$ & \\
\hline - Buruk & $2(100)$ & $0(0)$ & $2(100)$ & \\
\hline Berat badan lahir (kg) & & & & 0,147 \\
\hline - Normal $(\geq 2,5)$ & $22(41,5)$ & $31(58,5)$ & $53(100)$ & \\
\hline - Rendah $(<2,5)$ & $13(86,7)$ & $2(13,3)$ & $15(100)$ & \\
\hline Pemberian ASI & & & & 0,999 \\
\hline - Tidak pernah & $7(100)$ & $0(0)$ & $7(100)$ & \\
\hline - ASI parsial & $26(55,3)$ & $21(44,7)$ & $47(100)$ & \\
\hline - ASI eksklusif & $2(14,3)$ & $12(85,7)$ & $14(100)$ & \\
\hline Lama pendidikan ayah (tahun) & & & & 0,047 \\
\hline - $\leq 6$ & $10(71,4)$ & $4(28,6)$ & $14(100)$ & \\
\hline - $\overline{7}-9$ & $8(61,5)$ & $5(35,5)$ & $13(100)$ & \\
\hline - $10-12$ & $14(42,4)$ & $19(57,6)$ & $33(100)$ & \\
\hline • $\geq 13$ & $3(37,5)$ & $5(62,5)$ & $8(100)$ & \\
\hline Lama pendidikan ibu (tahun) & & & & 0,038 \\
\hline$\cdot \leq 6$ & $8(72,7)$ & $3(27,3)$ & $11(100)$ & \\
\hline - $\overline{7}-9$ & $11(68,8)$ & $5(31,3)$ & $16(100)$ & \\
\hline - $10-12$ & $11(37,9)$ & $18(62,1)$ & $29(100)$ & \\
\hline - $\geq 13$ & $5(41,7)$ & $7(58,3)$ & $12(100)$ & \\
\hline Suhu badan $\left({ }^{\circ} \mathrm{C}\right)$ & & & & 0,276 \\
\hline - $<38$ & $6(40,0)$ & $9(60,0)$ & $15(100)$ & \\
\hline - $38-39,4$ & $25(51,0)$ & $24(49,0)$ & $49(100)$ & \\
\hline - $\geq 39,5$ & $4(100)$ & $0(0)$ & $4(100)$ & \\
\hline Jumlah leukosit $\left(/ \mathrm{mm}^{3}\right)$ & & & & 0,012 \\
\hline$\bullet<5.000$ & $1(100)$ & $0(0)$ & $1(100)$ & \\
\hline - $5.000-10.000$ & $6(35,3)$ & $11(64,7)$ & $17(100)$ & \\
\hline - $10.001-15.000$ & $10(41,7)$ & $14(58,3)$ & $24(100)$ & \\
\hline - $>15.000$ & $18(69,2)$ & $8(30,8)$ & $26(100)$ & \\
\hline Lama sakit di rumah (hari) & & & & 0,007 \\
\hline - $\leq 3$ & $7(35,0)$ & $13(65,0)$ & $20(100)$ & \\
\hline - $\overline{4}-6$ & $11(44,0)$ & $14(56,0)$ & $25(100)$ & \\
\hline - $\geq 7$ & $17(73,9)$ & $6(26,1)$ & $23(100)$ & \\
\hline Pengobatan sebelum masuk rumah sakit & & & & 0,758 \\
\hline Tidak & $14(53,8)$ & $12(46,2)$ & $26(100)$ & \\
\hline - Ya & $21(50,0)$ & $21(50,0)$ & $42(100)$ & \\
\hline Penggunaan obat nyamuk di rumah & & & & 0,118 \\
\hline - Tidak & $5(33,3)$ & $10(66,7)$ & $15(100)$ & \\
\hline - Ya & $30(56,6)$ & $23(43,4)$ & $53(100)$ & \\
\hline Keluarga perokok (batang/hari) & & & & 0,035 \\
\hline - Tidak ada & $8(30,8)$ & $18(69,2)$ & $26(100)$ & \\
\hline - $<10$ & $7(58,3)$ & $5(41,7)$ & $12(100)$ & \\
\hline - 10-19 & $15(75,0)$ & $5(25,0)$ & $20(100)$ & \\
\hline - $\geq 20$ & $5(50,0)$ & $5(50,0)$ & $10(100)$ & \\
\hline Hasil biakan & & & & 0,054 \\
\hline • Positif & $21(63,6)$ & $12(36,4)$ & $33(100)$ & \\
\hline - Negatif & $14(40,0)$ & $21(60,0)$ & $35(100)$ & \\
\hline
\end{tabular}


ASI juga mengandung faktor pertumbuhan untuk pematangan organ, termasuk paru-paru. ${ }^{25}$ Distres pernapasan paling banyak terjadi pada pasien pneumonia yang tidak pernah mendapat ASI.

Tingkat pendidikan orang tua mempengaruhi status kesehatan keluarganya. Tingkat pendidikan yang lebih tinggi diharapkan dapat membawa serta perubahan pola pikir positif terhadap berbagai masalah termasuk masalah kesehatan, pencegahan penyakit, sanitasi lingkungan dan pengobatan penyakit. ${ }^{15,20}$ Tampak terdapat hubungan antara lama pendidikan ayah dan kejadian distres pernapasan pada anak dengan pneumonia $(p=0,047)$. Demikian juga adanya hubungan antara lama pendidikan ibu dan kejadian distres pernapasan pada anak dengan pneumonia $(\mathrm{p}=0,038)$.

Distres pernapasan terbanyak dijumpai pada pneumonia dengan suhu badan saat masuk rumah sakit $\geq 39,5^{\circ} \mathrm{C}(100 \%)$, suhu badan $38-39,4^{\circ} \mathrm{C}(51 \%)$ dan $\leq 38^{\circ} \mathrm{C}(40 \%)$. Namun tidak terdapat hubungan pada keduanya $(\mathrm{p}=0,276)$. Pengukuran suhu badan hanya dilakukan saat masuk rumah sakit, kemungkinan sebagian pasien telah meminum obat penurun panas sebelum masuk rumah sakit.

Pemeriksaan darah tepi pada pneumonia bakterial umumnya menunjukkan leukositosis. Apabila hasil pemeriksaan darah tepi menunjukkan leukopeni, sedangkan penyebabnya telah diketahui oleh bakteri, maka hal ini merupakan petunjuk prognosis penyakit tersebut lebih buruk. ${ }^{26}$ Distres pernapasan paling banyak terjadi pada pasien dengan jumlah leukosit $>15.000 / \mathrm{mm}^{3}$ (69,2\%). Pada pasien dengan jumlah leukosit $<5.000 / \mathrm{mm}^{3}$, terdapat hubungan antara kejadian distres pernapasan, dan biakan darah Staphylococcus.

Lama sakit di rumah mempengaruhi prognosis penyakit pneumonia, menggambarkan lama perjalanan penyakit. Juga dapat menggambarkan keadaan sosial ekonomi keluarga, keterlambatan mencari pelayanan medis dapat disebabkan karena faktor ekonomi atau tingkat pendidikan orang tua yang rendah. Distres pernapasan paling banyak terjadi pada pasien pneumonia dengan lama sakit di rumah $\geq 7$ hari $(73,9 \%)$ dan paling sedikit pada pasien dengan lama sakit di rumah $\leq 3$ hari $(35 \%)$. Pattisahusiwa ${ }^{20}$ mendapatkan bahwa pneumonia berat ditemukan pada $77,8 \%$ pasien yang lama sakit di rumah $>5$ hari, sedangkan pasien dengan lama sakit di rumah $\leq 3$ hari hanya $35,7 \%$ yang menderita pneumonia berat.
Kesadaran orang tua untuk mencari pelayanan medis bagi anaknya yang sakit akan menentukan prognosis penyakit anak tersebut. Pattisahusiwa ${ }^{20}$ mendapatkan bahwa $62,5 \%$ pasien dengan diagnosis pneumonia berat tidak pernah mendapatkan pengobatan sebelumnya, namun peneliti tidak mendapatkan hubungan di antara keduanya. Beberapa faktor dapat menjadi penyebab diantaranya beragam pengobatan yang diperoleh sebelum masuk rumah sakit, termasuk dari paramedis dan pengobatan sendiri oleh orang tua, keteraturan minum obat serta kesulitan untuk menelusuri jenis obat yang sudah diminum akibat tidak semua orang tua dapat mengingat nama obat yang sudah diminum oleh anaknya serta sebagian obat yang sudah diracik dalam bentuk puyer.

Pajanan terhadap asap rokok baik secara aktif maupun pasif, berhubungan dengan berbagai gangguan saluran napas. Asap rokok mengandung beberapa partikel yang dapat dihirup seperti hidrokarbon polisiklik, karbon monoksida, nikotin, nitrogen oksida dan akrolein yang dapat menyebabkan kerusakan epitel bersilia, menurunkan klirens mukosiliar serta menekan aktivitas fagosit dan efek bakterisid dari makrofag alveoli. ${ }^{15,27}$ Ditemukan hubungan antara keluarga perokok dan kejadian distres pernapasan pada anak dengan pneumonia $(\mathrm{p}=0,035)$. Sama halnya dengan asap rokok, obat nyamuk semprot maupun asap dari obat nyamuk bakar juga merupakan iritan inhalan yang dapat mempengaruhi perlangsungan penyakit pernapasan karena menyebabkan gangguan mekanisme pertahanan paru dengan terhambatnya transpor mukosiliar. ${ }^{23,27}$ Namun berdasarkan jenis obat nyamuk yang digunakan keluarga, obat nyamuk bakar merupakan penyebab distres pernapasan.

Kenyataan menunjukkan bahwa di negara berkembang, bakteri mempunyai peran jauh lebih besar sebagai penyebab pneumonia dibandingkan di negara maju. Pungsi paru adalah cara yang paling sensitif untuk mencari penyebab pneumonia pada anak. Namun karena bersifat sangat invasif, maka penggunaan cara ini untuk tujuan penelitian banyak ditentang. Pada tahun-tahun terakhir ini, informasi tentang etiologi pneumonia pada anak diperoleh dari biakan darah. ${ }^{14}$ Ditemukan distres pernapasan lebih banyak terjadi pada pasien pneumonia dengan hasil biakan darah positif $(63,6 \%)$ dibandingkan dengan yang negatif (40\%). Walaupun tidak bermakna secara statistik, namun terdapat kecenderungan adanya hubungan antara hasil biakan darah dan kejadian 
distres pernapasan pada anak dengan pneumonia $(\mathrm{p}=0,058)$. Berdasarkan jenis kuman, maka secara umum Staphylococcus merupakan terbanyak ditemukan, yaitu $24(72,7 \%)$ dari 33 biakan yang positif. Namun dari 24 pasien yang biakannya menunjukkan kuman Staphylococcus, hanya 15 (62,5\%) yang mengalami distres pernapasan. Seorang pasien dengan hasil biakan Streptococcus dan 5 pasien dengan hasil biakan kuman Proteus, semuanya (100\%) mengalami distres pernapasan.

Untuk mencari hubungan antara beberapa faktor risiko secara bersama-sama terhadap kejadian distres pernapasan maka dilakukan uji regresi logistik dengan prosedur stepwise. Hasil uji menunjukkan faktor lama sakit di rumah, adanya keluarga perokok dan hasil biakan, secara bersama-sama mempunyai hubungan bermakna dengan kejadian distres pernapasan pada anak dengan pneumonia $(\mathrm{p}<0,05)$.

\section{Kesimpulan}

Lama pendidikan ayah, lama pendidikan ibu, jumlah leukosit saat MRS, lama sakit di rumah dan adanya keluarga perokok memperngaruhi terjadinya distres pernapasan pada anak dengan pneumonia. Secara bersama-sama faktor lama sakit di rumah, adanya keluarga perokok dan hasil biakan mempunyai hubungan bermakna dengan kejadian distres pernapasan pada anak dengan pneumonia.

\section{Daftar Pustaka}

1. Azis AL. Gagal napas akut pada anak. Disampaikan pada: Continuing Education Ilmu Kesehatan Anak, Surabaya, 1 Nopember 1997.

2. American College of Emergency Physicians \& American Academy of Pediatrics. Respiratory distress. Chicago, Illinois: Advanced pediatric life support join task force; 2000:3-16.

3. Deliana E. Kegawatan respirasi. Disampaikan pada: Kongres Nasional Ilmu Kesehatan Anak XII, Bali, 30 Juni-4 Juli 2002.

4. Kumaat L. Pernapasan buatan pada anak. Disampaikan pada: Simposium gawat darurat anak, Manado, 26 Mei 2001.

5. DeBruin W, Notterman DA, Magid M, Godwin T, Johnston S. Acute hypoxemic respiratory failure in in- fant and children: clinical and pathologic characteristics. Crit Care Med 1992;20:1223-34.

6. Teo J. Kedaruratan pernapasan akut. Dalam: Ling WYC, Hock JTS, penyunting. Manual kedaruratan pada anak. Jakarta: Binarupa Aksara; 1993. h. 223-37.

7. Dobyns EL, Durmowicz AG, Henry DB, Loftness S, Stenmark KR. Critical care. Dalam: Hay WW, Groothuis JR, Hayward AR, Levin MJ, penyunting. Current pediatric diagnosis \& treatment. Edisi ke-13. Stanford, Connecticut: Appleton \& Lange; 1997. h. 331-7.

8. Djaja S. Prevalensi pneumonia dan demam pada bayi dan anak balita, SKDI 1991, 1994, 1997. Bal. Penelit. Kesehat. 26 (4) 1998/1999:134-43.

9. Sidhartani. Keselarasan pneumonia radiologik dengan klasifikasi World Health Organization (WHO). M.Med Indonesia 2000;35:143-7.

10. Rasmin. Diagnostik pneumonia nosokomial. Paru 1995; 15:101-4.

11. McCracken GH. Etiology and treatment of pneumonia. Pediatr Infect Dis J. 2000;19:373-7.

12. Wantania JM. Kumpulan kuliah pulmonologi anak FK Unsrat Manado.

13. Prober GC. Pneumonia. Dalam: Behrman RE, Kliegna R, Arvin AM, penyunting. Nelson Text book of pediatric. Edisi ke-15. Philadelphia: WB Saunders; 1996. h. 883-8.

14. WHO. Dasar pemikiran tata laksana pneumonia pada anak di sarana kesehatan dasar: Program pemberantasan infeksi saluran napas akut. WHO, Jenewa: 1-20.

15. Sidhartani. Epidemiology community acquired pneumonia pada anak. Kumpulan makalah lengkap. Simposium respirologi anak masa kini di Bandung, 1112 Desember 1998. Bagian Ilmu Kesehatan Anak FK UNPAD/RSUP Dr. Hasan Sadikin Bandung, 1998; I$\mathrm{I}_{8}$.

16. Dinas Kesehatan Dati I Propinsi Sulawesi Utama. Data penelitian bronkopneumonia di Sulawesi Utara tahun 1997.

17. Data kasus pneumonia di Bagian Ilmu Kesehatan Anak RSUP Manado. Tahun 2002. (tidak dipublikasi).

18. Sari TT, Karyana YPG, Syarif M. Morbiditas dan mortalitas pneumonia berat anak rawat inap di rumah sakit umum Praya. Journal Kedokteran YARSI 1999; 7:47-57.

19. Lengkong JV, Lengkey CJ, Wantania JM. Faktor-faktor yang berhubungan dengan bronkopneumonia pada anak balita yang dirawat di bagian anak RSUP Manado periode 1997-1998. Dipresentasikan pada KONIKA XI, Jakarta 4-7 Juli 1999. 
20. Pattihusiwa J. Penelitian hubungan beberapa faktor dengan kejadian pneumonia pada anak di RSU Gunung Wenang Manado. Tesis. Manado: Universitas Sam Ratulangi, 1994.

21. Wantania JM. Penyakit pneumonia pada anak: Permasalahan dan penanggulangannya. Kumpulan pidato para guru besar Fakultas Kedokteran UNSRAT 1983-1993.

22. Gaston B. Pneumonia. Pediatrics in review 2002; 23:132-40.

23. Said M. Kegagalan pernapasan akut pada bayi dan anak. Dalam: Tjokronegoro A, penyunting. Penatalaksanaan kegawatan pediatrik. Jakarta: FKUI; 1981. h. 34-45.

24. Wantania JM. Infeksi saluran pernapasan akut pada anak di RSU Gunung Wenang Manado. Prosiding lokakarya infeksi saluran pernapasan akut (ISPA) II. Ciloto,
Oktober 1989. Departemen Kesehatan Republik Indonesia Direktorat Jendral Pemberantasan Penyakit Menular \& Penyehatan Lingkungan Pemukiman 1989:51-8.

25. Sidi IPS, Suradi R, Masoara S, Boedihardjo SD, Marnoto W. Buku bacaan manajemen laktasi. Edisi ke2. Jakarta: Perkumpulan Perinatologi Indonesia; 2004. h. 1-13.

26. Wantania JM. Pneumonia berat pada anak. Simposium penyegar dan penambah ilmu kedokteran. Dies Natalis ke-41 Fakultas Kedokteran Universitas Sam Ratulangi. 27 Mei 2000. FK UNSRAT, 2000;1-11.

27. Sukar, Lubis A, Tugaswati T, Athena A, Kaasnodiharjo. Risiko relatif lingkungan sosial dan kimia terhadap kejadian penyakit ISPA pneumonia di Indramayu, Jawa Barat 1997;114:41-4. 